\title{
Sectorial Output Growth and Commercial Bank Credit Nexus in Nigeria
}

\author{
Adedigba Praise Abina ${ }^{a, *} \&$ Emeka Obi ${ }^{b}$ \\ ${ }^{a}$ Finance \& Banking Department, University of Port Harcourt, Port Harcourt. Nigeria \\ ${ }^{b}$ Harvard Concept Consulting, Port Harcourt, Rivers State, Nigeria
}

\begin{abstract}
This study investigates the nexus between sectorial output growth and commercial bank credit in Nigeria. Sectorial output growth was broken down into three different proxies which include production sector, Commercial sector and Service sector contribution to gross domestic product while bank credit to production sector, general commerce and service sector served as the independent variables which are used to proxy commercial bank credit. The study made use of secondary data obtained from Central Bank of Nigeria Statistical bulletin for the period 1981 to 2019. It employed Descriptive Statistics, Phillips-Perron (PP) Unit Root Test, Simple Regression Analysis and Granger Causality Test. The Granger Causality result showed that bi-directional causality is identified in the three models while there were positive and significant relationship between bank credit to production sector, general commerce, service sector and production sector contribution to gross domestic product, general commerce sector contribution to gross domestic product and service sector contribution to gross domestic product respectively. The paper therefore recommends that the regulatory authorities should prioritize more on increasing and easing the requirements needed from deficit spenders to secure credit from commercial banks in Nigeria.
\end{abstract}

Keywords: sectorial output growth, bank credit, commercial bank, granger causality test, Nigeria

\section{Introduction}

Effective and efficient use of available physical and financial resources leads to economic performance. These resources can be stimulated through banks intermediation process, the process whereby deposit money banks act as middlemen between surplus spending units and deficit spending units. This will definitely stimulate specialization and expertise in any economy. These banks are highly regulated by the apex bank, which is in a bid to add to their efficiency. The macro-economic objective in any country can be achieved through effective and efficient credit allocation, which will spontaneously accelerate economic development in developing countries. This credit is mainly finance (money). According to Ezirim (2005), finance can be seen as plastic commodity. As money which can serve as a medium of exchange, needed by various economic agents for productive purposes and operating expenses.

According to Ademu (2006) banks help to create self-employment by making credit facility available to expand the business in size and in diversification. In Nigeria, federal government over the years allocate funds to various sectors on a yearly basis in order to alleviate the burden that private individual bear in trying to expand their businesses. These facilities also help in creating employment opportunities.

Harrod and Domar (1882) pointed out that real income and output would only expand so long as net investment takes place; likewise, they both need to expand at the same rate at which capital stock production capacity is expanding. The various advances government allocate to different sectors in the country help to facilitate liquidity in the

\footnotetext{
* Corresponding author.

E-mail address: praise2009@yahoo.com (Adedigba Praise Abina)
} 
economy. The work of Mamman and Hashim (2014) established that banks cannot be ruled out in stimulating growth in any economy. Similarly, the work of Yakubub and Affoi (2014), Emmanuel, Abiola and Anthony (2015) attest that in order to have accelerated growth, there is need for allocation of credit to major sectors of the economy.

Melanie (2004) alluded that a well-functioning financial market is needed for development to take place. Equally, Oluitan (2012) observed that availability of external finance to firm makes the growth process faster than those firms that are limited to internal finance. Emmanuel et al (2015) opined that access to credit leads to an increase in productive capacity of a firm. Sanusi, (2012) also pointed out that inadequate capital is a major problem that contributes to the poor performance of any economy. In another investigation by Beck and Jerome (2005) and Boyreau-Debray (2003) confirmed that political bias, corruption and waste attributed to both the public and private sector are detrimental to growth in any country. The inability of small and medium scale business to secure financial resources creates a constrain and hence affect the performance of business and development that might result from it (Mambula 2002). This paper therefore strives to investigate the nexus relationship between sectorial output growth and commercial bank credit in Nigeria.

\section{Theoretical Underpinning}

\subsection{Theory of Financial Intermediation}

This theory holds that financial intermediation is a key prerequisite for economic growth. Empirical facts from Schumpeter (1934) Goldsmith (1969), Mckinnon and Shaw (1973), Shaw and Patrick (1979) support the financial intermediation theory in causing growth. The work of Schumpeter (1934) attest to the fact that hand-maids to entrepreneur are the financial institutions; finance follows while entrepreneurs lead. Ajie (2006) describes the process of financial intermediation as that which is concerned with the mechanism and technique of mobilizing savings or financial resources from the surplus to the deficit in the needy economy.

\subsection{Neo-Classical Growth Model}

This theory assumes that productivity is independent of capital investment, with productivity improvement in this context serving as the exogenous variable. The Neo-Classical Growth Model was first propounded by Robert Solow. He was of the opinion that capital investment only increases the growth rate in a country for just a temporary period. This is because if capital ratio to labour goes up, it indicates availability of capital for labour to work with while additional unit of marginal product declines making the economy to move backwards. A steady state will only be witnessed if capital and labour are growing at the same rate. In order for there to be an increase in growth rate in a country in the long run, there is need for improvement in capital and labour productivity as well as an increase in labour supply is needed to argument this change. This theory which articulates variation between countries in terms of growth is linked to technological change.

\subsection{Harrod-Domar Growth Model}

This model examined how investment can spur up growth. They pointed out that investment helps to increase capital stock (demand effect) and create income (supply effect) to rational investors. Again, for full employment to be attained, there is need for equal movement of real income and output in any country. There is also need for expansion in net investment which will spur up the capital formation process in the economy.

\subsection{Gap and Exigency Thesis}

This proposition states that the intermediation function (mobilization of funds) which banks perform in the economy leads to economic development. The growth of financial institution of any country is a major determinant of its economic growth. The higher the growth of financial system, the greater the chance of development of that economy. The funds mobilized serve as capital that can further be used for development purpose. A seasoned economist, 
Schumpeter (1911), strongly supports this view which he called finance led causal relationship. In different investigations by Greenwood and Jovanovic (1990), King and Mckinnon (1973), Levine (1993), Demirguc-Kunt and Levine (2008), Orji (2012), Ameche and Ibe (2014), they all accepted the supply leading hypothesis, which simply states that for growth to be achieved in any country, the financial system has to be developed. There is a bi-directional relationship between financial institution and economic development.

\subsection{Empirical Review}

Fapetu and Obalade (2015) investigated deposit money banks' credit allocation and its impact on the Nigerian economy. The study made use of multiple regression analysis. Three different government regimes, (1960-1985), (1986-1995) and (1996-2010) were used in the study. 52years accounts for the total data time span used. Real gross domestic product was used as proxy for the explained variable while advances to general commerce, production sector, advances to services and advances to others were used as proxies for the explanatory variables. In the intensive regulation regime, only advances to others has a positive (9.214851 co-efficient value) and significant relationship (0.0027 P-value) with the explained variable, while in the regulated regime only general commerce had a negative (-2.623469 co-efficient value) and insignificant relationship (0.8921 P-value) with the explained variable. The last regime showed that the advances to commercial sector contributed positively ( 0.213638 co-efficient value) and has significant relationship with real gross domestic product. The study concludes that the interest charged on loans given to any of the sectors or subsectors should be favourable.

In Nigeria, Courage and Leonard (2019) investigated how credit to manufacturing and agricultural sub-sectors affected economic growth. The study made use of the error correction technique and three models to carry out its investigation. Data on monetary policy rate, bank sectorial credit to manufacturing and agriculture subsectors, financial market development from 1981 to 2015 were gathered. The empirical result indicated that financial sector development enhances growth in the economy through credit they extend to manufacturing and agricultural subsectors. The study therefore recommends that there should be an increase in the quantum of credit disbursed to the aforementioned sectors. Iwedi, Igbanibo and Onuegbu (2015) examined domestic credit in Nigeria. The study showed that both in the short run and long run, credits to government and private sector correlate with gross domestic product after using data from 1980-2013. It was also discovered that contingent liabilities exact negative contribution (13.60207) to the explained variable. Opposite direction was noticed in the short run between contingent liability and the explained variable. The study concludes that in order to attain the pre-nominated objectives, there is need for effective utilization of the borrowed loan. From a different approach, Ali (2016) investigated banks' credit as drive for investment. The study proxied private sector credit and bank lending rate as explanatory variables while investment as the explained variable. The data were sourced from 1981 to 2012. The two explanatory variables used contributed significantly and have positive relationship with investment in the country. The result from the analysis also showed the presence of serial correlation between the variables used. Ali concluded by recommending that there is need for loan to be available to SME and agriculture which contribute essentially to the economy.

Commercial banking and economic growth in Nigeria, was examined by Okpala, Ezeanolue, and Edoko (2018). The study employed the Ordinary least Square (OLS) technique to ascertain if relationship exist between the variables specified and it was discovered that bank profit and financial intermediation have a positive and significant relationship with gross domestic product. The study strongly recommends that for banks not to run into bad debt, there is need for risk focused and rule based regulatory frame work, so as to improve the quality of asset in the bank. Obamuyi Edun and Kayode (2009) made use of 36 years' time series data to investigate manufacturing output and bank lending in Nigeria. The study made use of nine different proxies to investigate the effect of bank lending. From the result of vector error correction model, it was observed that only inflation and exchange rate contributed negatively and insubstantially related to manufacturing output. But the other variables (capacity utilization (0.7), gross domestic product (1.3) and lending rate (0.8)) contributed positively but in different degrees. They further recommend that there is need for collaboration between lending institution and government in other to increase output. Korkmaz (2015) examined the impact of bank credits on economic growth and inflation. The study made use of panel data. After conducting appropriate econometric tests, the unit root test result showed that economic growth and bank credit were stationary at level while inflation became stationary at first difference. It was presented that if 
appropriate savings are being channeled to the right investment, then it will contribute positively to economic development.

Mamman and Hashim (2014) employed secondary data to evaluate economic growth and bank lending, the study proxy financial intermediaries and aggregate bank lending as explanatory variable while real gross domestic product was used as explained variable. It found out that flow of credit to productive sector through the various policies the central bank initiates needs to be improved on. In Pakistan, Aurangzeb, (2012) selected ten banks to carry out his investigation on the banking sector and its contribution to growth, using times series data from 1981 to 2010 . The investigation tested for stationarity of the data and went further to test for reinforcement and multiple relationship. The study made use of total deposit, investment, interest and earnings, advances and profitability of the selected banks as the endogenous variables while gross domestic product was used as the exogenous variable. The result of the causality test relationship shows that only profitability has a negative $(-0.009$ P-value) contribution on gross domestic product whereas other variables exhibit a positive contribution. It was also discovered that all the endogenous variables are significant to the endogenous variables. However, bi-directional causal relationship was identified between profitability deposit and advances on economic growth. In addition, it was discovered that interest earnings has a uni-directional association flowing between itself to gross domestic product. The study opines that there is need to improve the financial sector most especially the banks in Pakistan. In a similar investigation by Shan and Jianhong (2006) in china, bi-directional connection was discovered between economic growth and financial development.

Yakubub and Affoi (2014) employed simple regression analysis to investigate bank credit and growth using time series data from 1992 to 2012. The investigation made use of private sector credit as the endogenous variable. The study discovered that this credit has a positive and significant relationship with GDP; about $3.132765 \%$ is what private sector credit contributes to gross domestic product. Thus, the study recommends that there is need to promote credit and a strong framework that will help to monitor and recover credit to the private sector. Emmanuel, Abiola and Anthony (2015) also carried out same investigation with that of Yakubub and Affoi (2014) but Emmanuel et al (2015) made use of quarterly data for 14 years. They also added more proxies in their model as well as using different endogenous variable (RGDP). The study made use of cointegration test while the model co-efficient was estimated using fully modified ordinary least square. The result from the fully modified ordinary least square for the first model, showed that all the endogenous variable used in the study contributed positively to the exogenous variable apart from government spending, while the same was noticed in model two but prime lending rate was the only one that exhibited the same character with that of government expenditure.

Emmanuel and Adegboyega (2014) employed financial repression hypothesis model to investigate banks and sectorial development in Nigeria. Making use of 41 years' time series data which is divided into three different administrations namely: intensive (liberalized banking), deregulation and guided deregulation administrations, (19701985), (1986-1995) and (1996-2010). The study proxied real gross domestic product as the exogenous variable while bank credit as endogenous variable. Simple regression analysis and causal relationship was conducted in the three different regimes. It was discovered in the first era (1970-1985), that bank credit had a positive $0.683384 \mathrm{P}$-value and significant association with RGDP while the causal analysis showed a uni-directional relationship flowing from GDP to bank credit. The second era (1986-1995) showed a positive (1.31 P-value) and significant association with RGDP while the causal analysis showed no causal relationship between the variables. The same result in the second era also applies to the third era but the contribution exogenous variable has on endogenous variable was $0.663363 \%$ which was less than that of the second era. It was also identified that if not for credit that was disbursed to the economy in the second era, (1986-1995) there would have been no growth because of the constant having a negative sign. The study accepted the employed hypothesis. There is need for regular review on policies that will accommodate entrepreneur to have access to loan which will help in speeding up economic growth. 


\section{Theoretical Underpinning}

The paper used the ex-post- facto research design. This study carried out an empirical investigation making use of time series data sourced from the Central Bank of Nigeria Statistical Bulletin Annual Report (1981-2019). This paper fills the gap identified from previous empirical works by conducting a sectorial causality analysis. All the sub-sectors are lumped up into three sectors: production, general commerce and service sector. The first sector which is production sector includes all credits allocated to Agriculture, forestry and fishery, manufacturing, mining and quarrying and real estate and construction. The next was general commerce sector which included loans allocated to domestic trade, exports and imports while that of service sector was composed of credit allocated to public utilities, transport, storage and communications, education and credit to financial institutions (finance, insurance and capital market). The dependent variable was proxied with three key variables which were used to capture gross domestic variable. Thus, the variables include agricultural sector contribution to gross domestic product and construction sector contribution to gross domestic product, quantitative data of these two key sectors are summed up to arrive at production sector contribution to gross domestic product. Commercial sector contribution to gross domestic product is arrived by summing trade sector contribution to gross domestic product and industrial sector contribution to gross domestic product. Finally, the service sector contribution to gross domestic product is composed of the total aggregate of items under the service sector in CBN Statistical Bulletin (Summation of composition of A-M service sector contribution to GDP) transport, information and communication, utilities, accommodation \& food services, finance $\&$ insurance, administrative and support services business services contributions to gross domestic product.

\subsection{Model Specification}

\subsubsection{The Functional Form of Model One}

Production sector contribution to gross domestic product is arrived at after summing the two functional variables in (1).

$$
\text { PSCGDP }=\mathrm{F}(\text { ASCGDP, } \mathrm{CSCGDP})
$$

Where:

PSCGDP $=$ Production sector contribution to gross domestic product.

ASCGDP $=$ Agricultural sector contribution to gross domestic product.

CSCGDP $=$ Construction sector contribution to gross domestic product.

Bank credit to production sector is arrived at after summing the four components listed in (2).

$$
\text { BCPS = F (BCAFFL, BCMAFL, BCMINQ, BCRECO })
$$

Where:

BCPS $=$ Bank credit to production sector

BCAFFL $=$ Bank credit for agriculture, forestry and fishery loan

BCMAFL $=$ Bank credit for manufacturing loan

BCMINQ = Bank credit for mining and quarying loan

BCRECO = Bank credit for real estate and construction loan

The functional form of equation One (1) and Two (2) can further be written as (3).

$$
\text { PSCGDP= F (BCPS) }
$$

It is imperative to include the estimation parameters; thus, we rewrite the equations 3 in econometric form as follows:

$$
\operatorname{PSCGDP}_{\mathrm{t}}=д_{0}+д_{1} \mathbf{B C P S}_{\mathrm{t}}+\ni \mathrm{i}
$$

Apriori Expectation $=\AA_{1},>0(><)$ 
Where:

PSCGDP = Production sector contribution to gross domestic product.

BCPS $=$ Bank credit to production sector

Д $_{0} \quad=$ Constant or intercept

эi $=$ error term

$д_{1}=$ estimation of parameters for the respective independent variables.

$(><) \quad=$ Bi-directional Causality

\subsubsection{The Functional Form of Model Two}

Commercial sector contribution to gross domestic product is arrived at after summing the two functional variables listed in (5).

$$
\text { CSCGDP }=\text { F (TSCGDP, ISCGDP) }
$$

Where:

CSCGDP $=$ Commercial sector contribution to gross domestic product.

TSCGDP $=\quad$ Trade sector contribution to gross domestic product.

ISCGDP $=\quad$ Industrial sector contribution to gross domestic product.

Bank credit to general commercial sector is arrived at after summing the three components listed in (6).

$$
\text { BCGCS = F (BCDOMST, BCEXPT, BCIMPT) }
$$

Where:

BCGCS $=$ Bank credit to general commerce

BCDOMST $=$ Bank credit for domestic trade

BCEXPT = Bank credit for exports

BCIMPT $=$ Bank credit for imports.

The functional form of equation Five and Six can further be written as (7).

\section{$\mathrm{CSCGDP}=\mathrm{F}(\mathrm{BCGCS})$}

The estimation parameter in equation 7 is thus re-written in econometric form as follows:

$$
\operatorname{CSCGDP}_{\mathrm{t}}=\mathrm{u}_{0}+\mathrm{\tau}_{2} \text { BCGCS }_{\mathrm{t}}+\Phi \mathrm{i}
$$

Apriori Expectation $=\mathrm{\Psi}_{2}>0(><)$

Where:

CSCGDP $=$ Commercial sector contribution to gross domestic product.

BCGCS $=$ Bank credit to general commerce

$\mathrm{u}_{0} \quad=$ Constant or intercept

Фi $\quad=$ error term

$\mathrm{\Psi}_{2}=$ estimation of parameters for the respective independent variables.

$(><) \quad=$ Bi-directional causality

\subsubsection{The Functional Form of Model Three}

Service sector contribution to gross domestic product is arrived at after summating up the composition of (A-M) service sector contribution to GDP in CBN Statistical Bulletin in (9).

$$
\text { SSCGDP }=\text { F }(\text { TSCGDP, ISCGDP })
$$


Where:

SSCGDP $=$ Service sector contribution to gross domestic product.

TCGDP = Transport contribution to gross domestic product

INFCO = Information and communication contribution to gross domestic product

UTIL = Utilities contribution to gross domestic product

ACFS = Accommodation $\&$ food services contribution to gross domestic product

FINIS = Finance $\&$ insurance contribution to gross domestic product

ADMSS = Administrative and support services contribution to gross domestic product

A-M = Summation of composition of A-M service sector contribution to GDP.

Bank credit to service sector is arrived at after summing up the component listed in (10);

BCSS = F (BCPU, BCFT, BCBC, BCE, BCFI)

Where:

BCSS $=$ Bank credit to service sector

$\mathrm{BCPU}=$ Bank credit to public utilities

BCFT = Bank credit for transport

$\mathrm{BCSC}=$ Bank credit for storage and communications

$\mathrm{BCE}=$ Bank credit for education

BCFI $=$ Bank credit to financial institutions (finance, insurance and capital market).

The functional form of equation Nine and Ten can further be written as equation (11):

$$
\text { SSCGDP }=\text { F }(\text { BCSS })
$$

The estimation parameter in equation 10 is thus, re-written in econometric form as follows:

$$
\operatorname{SSCGDP}_{\mathrm{t}}=\sigma_{0}+\sigma_{3} \mathbf{B C S S}_{\mathrm{t}}+\mathrm{Ui}
$$

Apriori Expectation $=\sigma_{3}>0 .(><)$

Where:

SSCGDP $=$ Service sector contribution to gross domestic product

BCSS $=$ Bank credit to service sector

$\sigma_{0} \quad=\quad$ Constant or intercept

$\mathrm{Ui} \quad=\quad$ error term

$\sigma_{3} \quad=\quad$ estimation of parameters for the respective independent variables.

$(><) \quad=\quad$ Bi-directional causality

Apriori Expectation $=\sigma д 1,>0$ ч $2>0_{3}>0$.

From the above Apriori expectation we expect a positive change and a bidirectional relationship $(><)$ between the two variables under investigation in each of the model.

\subsection{Estimation Tools for Analysis}

\subsubsection{Unit Root Test}

It is essential to test the stationarity of the variables by means of Phillips-Perron (PP) in the first difference form. The unit root test also helps us to check if the variables are mean reverting that is, they have constant mean, constant variance and constant covariance. 
The Model Expression is:

$$
\Delta y_{1}=\alpha_{o}+\alpha_{1} y_{i-1}+\sum_{i=1}^{n} \alpha_{1} \Delta y i-1+\delta_{1}+e_{1}
$$

Where;

$$
\begin{array}{ll}
\mathrm{a}_{0} & =\text { intercept } \\
\mathrm{t} & =\text { the time or trend of variable } \\
\Delta & =\text { first difference operator } \\
y_{1} & =\text { variable of choice } \\
\alpha_{\mathrm{i}} & =\text { constant parameters } \\
e_{1} & =\text { stationary stochastic process }
\end{array}
$$

Ho: $\alpha_{1}=0$; i.e. there is a unit root

$\mathrm{H} 1: \alpha_{1}=0$; i.e. there is no unit root

Decision Rule: if the computed Augmented Dickey Fuller (ADF) test statistics exceeds that of the McKinnon critical values in absolute terms, the null hypothesis will be rejected. This indicates that the time series data are stationary thus data is confirmed as appropriate for use in estimating the economic relationships.

\subsubsection{Granger Causality Test}

Model Expression;

$$
Y_{t}=\alpha_{0}+\sum_{\mathrm{t}=1}^{\mathrm{n}} \alpha_{1}^{\mathrm{y}} Y_{\mathrm{t}-1} \sum \underset{\mathrm{t}=1}{\mathrm{n}} \boldsymbol{\alpha}_{1} \mathrm{x}
$$

and;

$$
X_{t}=\beta_{0}+\sum_{\mathrm{t}=1}^{\mathrm{n}} \beta_{1}^{\mathrm{y}} Y_{\mathrm{t}-1} \sum \mathrm{x}_{\mathrm{t}=1}^{\mathrm{n}} \beta_{1} X Y_{t}
$$

This will evaluate the ability to forecast variables among each other. It proposed that just as the past can cause or forecast the future, it is very obvious that the future can also predict or forecast the past. Hence $X$ granger cause $Y$ if the past value of $X$ is utilized to forecast the future value of $Y$. In time series data variable $X$ is said to granger cause variable $Y$ if the current value of $Y\left(Y_{t}\right)$ is conditional on the past values of $X\left(X_{t-1}, X_{t-2}, \ldots, X_{\mathrm{o}}\right)$ and thus the history of $X$ is likely to help predict $Y$ (Konya, 2004). In this study, the Granger Causality test will be used to examine the dimension and linkage between sectorial output growth and commercial bank credit in Nigeria.

\subsubsection{Causality, Model One}

$$
\begin{aligned}
& \Delta \ln \text { PSCGDP }_{t}=u+\sum_{i=1}^{n} \theta_{l \Delta \ln _{\text {PSCGDP }} t-1}+\sum_{i=1}^{n} \theta_{l \Delta \ln \text { BCPS }_{t-1}+\text { II } t} \\
& \Delta \ln \mathbf{B C P S}_{t}=u+\sum_{i=1}^{n} \theta_{l \Delta \ln \mathbf{B C P S}_{t-1}}+\sum_{i=1}^{n} \theta_{l \Delta \ln \operatorname{PSCGDP}_{t-1}}+\ni \mathrm{I} t
\end{aligned}
$$

3.2.4. Causality, Model Two

$$
\Delta \ln \operatorname{CSCGDP}_{t}=u+\sum_{i=1}^{n} \theta_{l \Delta \ln \operatorname{CSCGDP}_{t-1}}+\sum_{i=1}^{n} \theta_{l \Delta \ln \mathbf{B C G C S}_{t-1}+\Phi \mathrm{i} t}
$$




$$
\Delta \ln \mathbf{B C G C S}_{t}=u+\sum_{i=1}^{n} \theta_{l \Delta \ln \mathbf{B C G C S}_{t-1}}+\sum_{i=1}^{n} \theta_{l \Delta \ln \operatorname{CSCGDP}_{t-1}}+\Phi \mathrm{i} t
$$

3.2.5. Causality, Model Three

$$
\begin{aligned}
& \Delta \ln \mathbf{S S G D P}_{t}=u+\sum_{i=1}^{n} \theta_{l \Delta \ln \operatorname{SSGDP}_{t-1}}+\sum_{i=1}^{n} \theta_{l \Delta \ln \mathbf{B C S S}_{t-1}+\mathrm{Uit}} \\
& \Delta \ln \mathbf{B C S S}_{t}=u+\sum_{i=1}^{n} \theta_{l \Delta \ln \mathbf{B C S S}_{t-1}}+\sum_{i=1}^{n} \theta_{l \Delta \ln \operatorname{SSGDP}_{t-1}}+\mathrm{Uit}
\end{aligned}
$$

\section{Findings}

\subsection{Descriptive Analysis}

The nature of the data is first considered using descriptive statistics. Below represents the result of the descriptive statistics,

\begin{tabular}{lcccccc}
\hline & PSCGDP & BCPS & CSCGDP & BCGCS & SSCGDP & BCSS \\
\hline Mean & 2376686. & 413613.1 & 397359.5 & 103020.9 & 3457980. & 56434.29 \\
Median & 1630.228 & 214.6123 & 121.8200 & 26.70920 & 2146.360 & 1.692400 \\
Maximum & 33402357 & 8097723. & 6031061. & 2049290. & 46311834 & 1132746. \\
Minimum & 28.09010 & 5.088900 & 6.100000 & 1.475000 & 64.24000 & 0.000000 \\
Std. Dev. & 8341177. & 1796107. & 1406513. & 447933.1 & 12111980 & 243736.1 \\
Skewness & 3.203739 & 4.069038 & 3.288272 & 4.072273 & 3.179766 & 4.079352 \\
Kurtosis & 11.33377 & 17.55826 & 12.07970 & 17.59432 & 11.12176 & 17.67380 \\
Jarque-Bera & 179.5747 & 452.0282 & 204.2492 & 453.9079 & 172.9107 & 458.0630 \\
Probability & 0.000000 & 0.000000 & 0.000000 & 0.000000 & 0.000000 & 0.000000 \\
& & & & & & \\
Sum & & & & & & \\
Sum Sq. Dev. & $2.64 \mathrm{E}+15$ & $1.23 \mathrm{E}+14$ & $7.52 \mathrm{E}+13$ & $7.62 \mathrm{E}+12$ & $5.57 \mathrm{E}+15$ & $2.26 \mathrm{E}+12$ \\
& & & & & & 39 \\
Observations & 39 & 39 & 39 & 39 & & 39 \\
\hline So & & & & &
\end{tabular}

Source: Output Result from E-views 10.

From the descriptive result above, SSCGDP has the highest mean value of (3457980) followed by PSCGDP (2376686). mean value then BCSS with (56434.29), CSCGDP (397359.5), BCGCS (103020.9) and PSCGDP (2376686.). BCSS has the lowest median value of 1.692400 followed by BCGCS with 26.70920 median value, CSCGDP with 121.8200 median value, then BCPS 214.6123, PSCGDP 1630.228 median value and finally SSCGDP with the highest median value of 2146.360 . None of the variable is discovered to be platykurtic but leptokurtic in nature since the kurtosis value is greater than 3 in each scenario.

\subsection{Phillips-Perron (PP) Unit Root Test}

In order to test for the order of stationarity between PSCGDP, BCPS, CSCGDP, BCGCS, SSCGDP and BCSS variables used the Phillips-Perron (PP) Unit Root Test was used. The PP test helped in ascertaining the next tool to be employed. 
Table 2 Phillips-Perron (PP) Result

\begin{tabular}{ccccc}
\hline Variable & PP Test Statistic & $\mathbf{5 \%}$ & $\begin{array}{c}\text { Order of } \\
\text { Integration }\end{array}$ & Prob. \\
\hline D(PSCGDP) & -5.095354 & -2.943427 & $\mathrm{I}(1)$ & 0.0002 \\
D(BCPS) & -6.404088 & -3.536601 & $\mathrm{I}(1)$ & 0.0000 \\
D(CSCGDP) & -4.327088 & -3.536601 & $\mathrm{I}(1)$ & 0.0078 \\
D(BCGCS) & -6.745841 & -3.536601 & $\mathrm{I}(1)$ & 0.0000 \\
D(SSCGDP) & -6.028336 & -3.536601 & $\mathrm{I}(1)$ & 0.0001 \\
D(BCSS) & -6.018077 & -3.536601 & $\mathrm{I}(1)$ & 0.0001 \\
\hline
\end{tabular}

Source: Authors Compilation from Output Result of E-views 10

The result presented in table 1 above validate the condition for usability of data. It was discovered that PSCGDP BCPS CSCGDP BCGCS SSCGDP and BCSS became stationary at level one 1(1). Thus, the data is not spurious and can be used for forecasting.

\subsection{Simple Regression and Granger Causality Result Analysis of Model One}

Table 3 Equation $4\left(\right.$ PSCGDP $_{t}=д_{0}+д_{1}$ BCPS $\left._{t}+э i\right)$

Dependent Variable: PSCGDP

Method: Least Squares

Date: 08/01/20 Time: 18:05

Sample: 19812019

Included observations: 39

\begin{tabular}{lllll}
\hline \hline \multicolumn{1}{c}{ Variable } & Coefficient & Std. Error & t-Statistic & Prob. \\
\hline \multicolumn{1}{c}{ C } & 763199.1 & 754171.9 & 1.011970 & 0.3181 \\
\multicolumn{1}{c}{ BCPS } & 3.900958 & 0.414258 & 9.416741 & 0.0000 \\
\hline \hline R-squared & 0.705590 & Mean dependent var & 2376686. \\
Adjusted R-squared & 0.697633 & S.D. dependent var & 8341177. \\
S.E. of regression & 4586640. & Akaike info criterion & 33.56511 \\
Sum squared resid & $7.78 E+14$ & Schwarz criterion & 33.65042 \\
Log likelihood & -652.5197 & Hannan-Quinn criter. & 33.59572 \\
F-statistic & 88.67502 & Durbin-Watson stat & 1.897925 \\
Prob(F-statistic) & 0.000000 & & \\
\hline \hline
\end{tabular}

Source: Output Result from E-views 10.

Result Analysis

From the simple regression above it can be seen that there is a positive and significant relationship between bank credit to production sector (BCPS) and production sector contribution to gross domestic product (PSCGDP). The computed Adjusted R-Squared obtained is 0.697633 , this implies that $70 \%$ variation in PSCGDP (model one proxy for sectorial output) is explained by the selected explanatory variables within the period of study while the remaining $30 \%$ variation are explained by other variables that are not captured in the model. Thus, for every one percent increase in BCPS, it leads to about 3.900958\% to PSCGDP, meaning that the earlier apriori expectation ( $д_{1}>0$ ) can be accepted. The probability value also showed that statistical significant relationship is noticeable between BCPS and PSCGDP. 
Pairwise Granger Causality Tests

Date: 08/01/20 Time: 15:55

Sample: 19812019

Lags: 2

\begin{tabular}{lccc}
\hline \hline Null Hypothesis: & Obs & F-Statistic & Prob. \\
\hline \hline PSCGDP does not Granger Cause BCPS & 37 & $\begin{array}{c}15.10609 \\
22.5536\end{array}$ & 0.0000 \\
BCPS does not Granger Cause PSCGDP & & & 0.0005 \\
\hline \hline
\end{tabular}

Source: Output Result from E-views 10.

\section{Result Analysis}

From the above result, it can be seen that production sector contribution to gross domestic product (PSCGDP) granger cause bank credit to production sector (BCPS). BCPS also causes a change in PSCGDP. This means past value of PSCGDP causes a change in BCPS. Also, past value of BCPS causes a change in PSCGDP. Thus, there is re-enforcement or bi-directional relationship between PSCGDP and that of BCPS. It can therefore be concluded that production sector contribution to gross domestic product (PSCGDP) greatly cause a change in bank credit to production sector (BCPS), likewise we can also deduce from the result above that bank credit to production sector causes a positive noticeable change in production sector output which affects gross domestic product. Thus, our earlier anticipated apriori expectation can be accepted $\left(д_{1}><\right)$.

\subsection{Simple Regression and Granger Causality Result Analysis of Model Two}

Table 5 Equation $8\left(\operatorname{CSCGDP}_{\mathrm{t}}=\mathrm{u}_{0}+\mathrm{u}_{2}\right.$ BCGCS $\left._{\mathrm{t}}+\Phi \mathrm{i}\right)$

Dependent Variable: CSCGDP

Method: Least Squares

Date: 08/01/20 Time: 18:20

Sample: 19812019

Included observations: 39

\begin{tabular}{lllll}
\hline \hline \multicolumn{1}{c}{ Variable } & Coefficient & Std. Error & t-Statistic & Prob. \\
\hline \hline \multicolumn{1}{c}{ BCGCS } & 115270.9 & 114709.2 & 1.004896 & 0.3215 \\
\multicolumn{1}{c}{2.738170} & 0.252666 & 10.83713 & 0.0000 \\
\hline \hline R-squared & 0.760430 & Mean dependent var & 397359.5 \\
Adjusted R-squared & 0.753955 & S.D. dependent var & 1406513. \\
S.E. of regression & 697671.5 & Akaike info criterion & 29.79880 \\
Sum squared resid & $1.80 \mathrm{E}+13$ & Schwarz criterion & 29.88412 \\
Log likelihood & -579.0767 & Hannan-Quinn criter. & 29.82941 \\
F-statistic & 117.4434 & Durbin-Watson stat & 1.864872 \\
Prob(F-statistic) & 0.000000 & & \\
\hline \hline
\end{tabular}

Source: Output Result from E-views 10.

Result Analysis

apriori expectation $\mathrm{\Psi}_{2}>0$ 
From the above simple linear regression model, the adjusted R-Squared obtained is 0.753955 . This implies that $75 \%$ variation in commercial sector contribution to gross domestic product (CSCGDP) (proxy for sectorial output, model 2 ) is explained by the selected explanatory variables within the period under investigation while the remaining $25 \%$ variation are explained by other variables that are not captured in the model. It was discovered that bank credit to general commerce (BCGCS) has a positive (co-efficient value of 2.738170) and statistical significant relationship (Pvalue of 0.0000) with commercial sector contribution to gross domestic product (CSCGDP). Thus, for every one percent increase in BCGCS, it will lead to about $2.738170 \%$ increase in CSCGDP.

Table 6 Granger Causality (Equations 18 and 19)

Pairwise Granger Causality Tests

Date: 08/01/20 Time: 16:07

Sample: 19812019

Lags: 2

\begin{tabular}{lccc}
\hline \hline Null Hypothesis: & Obs & F-Statistic & Prob. \\
\hline \hline BCGCS does not Granger Cause CSCGDP & 37 & 6.76659 & 0.0035 \\
CSCGDP does not Granger Cause BCGCS & & 8.72358 & 0.0009 \\
\hline \hline
\end{tabular}

Source: Output Result from E-views 10.

Result Analysis

From the above result, it was discovered that bank credit to general commerce (BCGCS) causes a change in commercial sector contribution to gross domestic product (CSCGDP). This also suggests that reinforcement relationship is identified between BCGCS and CSCGDP. Past values of BCGCS can be use to predict the future value of CSCGDP. Similarly, BCGCS past values can also forecast/predict the future value of CSCGDP. Relying on the apriori expectation earlier stated $\left(\mathrm{\Psi}_{2},>0\right.$, it can therefore be accepted since both variables cause a change in each other.

\subsection{Simple Regression and Granger Causality Result Analysis of Model Three}

Table 7 Equation $12 \operatorname{SSCGDP}_{\mathrm{t}}=\sigma_{0}+\sigma_{3} \mathrm{BCSS}_{\mathrm{t}}+\mathrm{Ui}$

Dependent Variable: SSCGDP

Method: Least Squares

Date: 08/01/20 Time: 18:34

Sample: 19812019

Included observations: 39

\begin{tabular}{lcccc}
\hline \hline \multicolumn{1}{c}{ Variable } & Coefficient & Std. Error & t-Statistic & Prob. \\
\hline \hline \multicolumn{1}{c}{ C } & 1160908. & 1158119. & 1.002408 & 0.3227 \\
\multicolumn{1}{c}{ BCSS } & 40.70347 & 4.686443 & 8.685366 & 0.0000 \\
\hline \hline R-squared & 0.670923 & Mean dependent var & 3457980. \\
Adjusted R-squared & 0.662029 & S.D. dependent var & 12111980 \\
S.E. of regression & 7041336. & Akaike info criterion & 34.42241 \\
Sum squared resid & $1.83 \mathrm{E}+15$ & Schwarz criterion & 34.50773 \\
Log likelihood & -669.2371 & Hannan-Quinn criter. & 34.45302 \\
F-statistic & 75.43558 & Durbin-Watson stat & 1.892158 \\
Prob(F-statistic) & 0.000000 & & \\
\hline \hline
\end{tabular}


Source: Output Result from E-views 10.

\section{Result Analysis}

The adjusted R-Squared obtained is 0.662029 , implying that there is $75 \%$ variation in the service sector contribution to gross domestic product (proxy for sectorial output, model three) is explained by the selected explanatory variables within the period while the remaining $34 \%$ variation are explained by other variables that are not captured in the model. Bank credit to service sector (BCSS) has a positive (co-efficient value of 0.0000) and significant relationship (P-value of 0.0000) with service sector contribution to gross domestic product (SSCGDP). Therefore, for every one percent increase in BCSS, it will lead to about $40.70347 \%$ to SSCGDP. Thus, the study therefore accepts the apriori expectation $\left(\sigma_{3}>0\right)$ stated in the above third model.

Table 8 Granger Causality (Equation 20 and 21)

Pairwise Granger Causality Tests

Date: 08/01/20 Time: 16:15

Sample: 19812019

Lags: 2

\begin{tabular}{lccc}
\hline \hline Null Hypothesis: & Obs & F-Statistic & Prob. \\
\hline \hline BCSS does not Granger Cause SSCGDP & 37 & 4.80808 & 0.0152 \\
SSCGDP does not Granger Cause BCSS & & 6.87309 & 0.0033 \\
\hline \hline
\end{tabular}

Source: Output Result from E-views 10.

\section{Result Analysis}

From the above result, it can be deduced that bi-directional causality could be seen between the two variables, that is; service sector contribution to gross domestic product (SSCGDP) granger causes bank credit to service sector (BCSS). Equally, BCSS causes a change in SSCGDP. This also means that past values of SSCGDP causes a change in BCSS and vice versa $\left(\sigma_{3}><\right)$. Thus, the apriori expectation can be accepted.

\section{Summary Findings}

The study attempted to explain the causal relationship between sectorial output growth and commercial bank credit in Nigeria from 1981-2019, using the simple regression analysis and granger causality statistical technique. The data used for the research work were secondary in nature and were obtained from the Statistical Bulletin of the Central Bank of Nigeria (CBN). The descriptive analysis was conducted to ascertain the nature of the variables, followed by the Phillips-Perron (PP) test which was applied after determining stationarity of the variables. The simple regression analysis was used to ascertain the relationship between the variables. It was discovered from the simple regression result in model one (1) that there is a positive and significant relationship between bank credit to production sector (BCPS) and production sector contribution to gross domestic product (PSCGDP). In model two (2), bank credit to general commerce (BCGCS) has a positive and statistical significant relationship with commercial sector contribution to gross domestic product (CSCGDP). Finally, it was discovered in the third model (3) that bank credit to service sector (BCSS) has a positive and significant relationship with service sector contribution to gross domestic product (SSCGDP). The granger causality result was employed to ascertain the direction of causality in the three different specified models. It was discovered from the Pairwise Granger Causality Tests that bi-directional causality is identified between (PSCGDP and BCPS), (BCGCS and CSCGDP) and (SSCGDP and BCSS). 


\section{Conclusion and Recommendations}

From the different granger causality results in the above model, it can be statistically and logically concluded that bank credit causes a change in contribution to growth in various sectors of the economy. It is observed that development of financial sector enhances growth which validates the hypothesis which states that financial sector development enhances growth in the economy. Therefore, the study recommends that the regulatory authorities need to prioritize more on increasing and easing the requirements that are needed by deficit spenders to secure credit from financial institutions. The study also points out that financial institutions need to structure flexible credit scheme for its current and potential customers. By so doing, it will make the financially excluded customers to become included in the credit scheme which will increase production and go a long way to accelerate economic growth.

\section{References}

Ademu, W.A., (2006). The informal sector and employment generation in Nigeria. Proceeding of the 2006 Annual Conference of the Nigeria Economic Society, in Calabar, August 22nd-24 ${ }^{\text {th }}$.

Ali, J.I, Jatau, S. \& Ashami, P, I. (2016), Deposit money banks' credit and investment drive of developing economies: Empirical Evidence from Nigeria. Asian Journal of Agricultural Extension, Economics \& Sociology. 11(1), 1 12. DOI: $10.9734 / A J A E E S / 2016 / 25134$.

Ameche, B.C, \& Ibe, R.C. (2014). Impact of bank credit on economic growth in Nigeria: Application of Reduced Vector Auto Regressive (VAR) technique. European Journal of Accounting Auditing and Finance Research. 2(9), $11-21$.

Aurangzeb, (2012). Contributions of banking sector in economic growth: A case of Pakistan. Economics and Finance Review. 2(6), $45-54$.

Beck T. Cull, R. \& Jerome, A. T. (2005) Bank privatization and performance: Empirical Evidence from Nigeria. World Bank Policy Research Working Paper No: 3511.

Boyreau-Debray, G. \& Shang-Jin, W. (2005) Pitfalls of a state-dominated financial system: The Case of China. NBER Working Paper 11214.

Courage, O.E, \& Leonard, N.A (2019) Impact of commercial banks' credit to the real sector on economic growth in Nigeria. Oradea Journal of Business and Economics. 1(4), 38-46.

Demirguc-Kunt, A. \& Levine R. (2008) Finance, financial sector policies and long run growth. The World Bank Development Research Group, Policy Research Working Paper 4469.

Emecheta, B. C. \& Ibe, R. C. (2014). Impact of bank credit on economic growth in Nigeria: Application of Reduced Vector Autoregressive (VAR) Technique. European Journal of Accounting Auditing and Finance Research. $9(2), 11-21$.

Emmanuel O. O, Abiola O. A \& Anthony O. U (2015). Impact of private sector credit on Economic Growth in Nigeria. CBN Journal of Applied Statistics. 2(6), 81.

Emmanuel, O.O. \& Adegboyega, E. (2014). Banks and economic growth in Nigeria: A Re-Examination of the Financial Repression Hypothesis. American Journal of Business and Management. 1(3), 1-9 DOI: $10.11634 / 216796061403516$.

Fapetu, O. \& Obalade, A. A. (2015) Sectoral allocation of banks' credit and economic growth in Nigeria. International Journal of Academic Research in Business and Social Sciences. 5, (6). ISSN: 2222-6990. DOI: 10.6007/IJARBSS/v5-i6/1666 URL: http://dx.doi.org/10.6007/IJARBSS/v5-i6/1666.

Iwedi, M., Igbanibo, D.S. \& Onuegbu, O. (2015). Bank domestic credits and economic growth nexus in Nigeria (1980-2013). International Journal of Finance and Accounting. 4(5), 236-244. DOI: 10.5923/j.ijfa.20150405.02.

King, R. G. \& Levine R. (1993) Financial intermediation and economic development. In: Financial Intermediation in the Construction of Europe, Eds: C. Mayer and X. Vives, London: Centre for Economic Policy Research: 156189.

Konya, L. (2004). Unit-root, Cointegration and Granger Causality Test Results for Export and Growth in OECD Countries. International Journal of Applied Econometrics and Quantitative Studies. 1(2), 73-94. 
Korkmaz, S. (2015). Impact of bank credits on economic growth and inflation. Journal of Applied Finance \& Banking. 1(5), 57-69.

Mambula, C. (2002). Perceptions of SME growth constraints in Nigeria. Journal of Small Business Management. $1(40), 58-65$.

Mamman, A \& Hashim, Y.A (2014). Impact of bank lending on economic growth in Nigeria. Research Journal of Finance and Accounting. 18(15).

McKinnon R. (1973) Money and capital in economic development (Washington: The Brookings Institute).

Melanie Feakins (2004). Commercial bank lending to SMEs in Poland. Small Business Economics Springer Netherlands. 23(1), 51-70.

Obamuyi, T.M, Edun, A.T \& Kayode, O.F. (2009). Bank lending, economic growth and the performance of the manufacturing sector in Nigeria. European Scientific Journal. 1(8).

Okpala, N.E, Ezeanolue, U.S, \& Edoko, T.D (2018) Commercial banking and economic growth in Nigeria. Open Journal of Economics and Commerce. 1(1), 68-75.

Oluitan, R. O. (2012). Bank credit and economic growth: Evidence from Nigeria. International Business and Management. 5(2), 102-110.

Orji, A. (2012). Bank savings and bank credits in Nigeria: Determinants and impact on economic growth. International Journal of Economics and Financial Issues. 2(3), 357-372.

Sanusi, L. S. (2012). Banking reform and its impact on the Nigerian economy. Lecture presented at the University of Warwick's Economic Summit, UK, Feburary, 17.

Shan, J. \& Jianhong, Q. (2006). Does financial development lead to economic growth? The case of China. Annals of Economics and Finance. 1(1), 231-250.

Yakubu, Z. \& Affoi, A.Y. (2014). An analysis of commercial banks' credit on economic growth in Nigeria, Current Research Journal of Economic Theory. 6(2), 11-15. 